\title{
The Semantics of the Plural Pronoun Construction
}

\author{
Masha Vassilieva and Richard K. Larson \\ SUNY - Stony Brook
}

The Russian comitative construction illustrated in (1) raises a simple puzzle for compositional semantics. As the glosses show, the subject phrase my s Petej is ambiguous between the meaning of 'we + Peter' or 'I + Peter'. Since Petej refers to Peter, a natural conjecture is that $m y$ is simply ambiguous between 'we' and ' $I$ ':

$$
\begin{aligned}
& \text { My s Petej pojd'om domoj. } \\
& \text { ?? with Peter-INSTR will-go home }
\end{aligned}
$$

a. We + Peter will go home.'

b. 'I + Peter will go home.'

Surprisingly, this conjecture is not correct. As (2) shows, when the comitative is absent, $m y$ unambiguously means 'we'; it cannot mean 'I'.

$$
\begin{aligned}
& \text { My pojd'om domoj. } \\
& \text { we will-go home } \\
& \text { 'We will go home.' } \\
& \text { *'I will go home.' }
\end{aligned}
$$

These data pose a straightforward question: if $m y$ always means 'we', then how does the reading in (1b) arise? How does 'we + Peter' come to mean 'we two'? The question is in fact a general one. As (3a) and (4a) show, Russian plural pronouns all display the ambiguity in (1) when accompanied by a comitative; and all are equally unambiguous when occurring alone (cf. (3b) and (4b)):

$$
\begin{aligned}
& \text { a. Vy s Petej pojd'ote domoj. } \\
& \text { ?? with Peter-INSTR will-go home } \\
& \text { 'You (pl) }+ \text { Peter will go home.' } \\
& \text { 'You (sg) }+ \text { Peter will go home.' }
\end{aligned}
$$
b. Vy pojd'ote domoj. you(pl) will-go home 'You(pl) will go home.' *'You(sg) will go home.'

a. Oni s Petej pojdut domoj. ?? with Peter-INSTR will-go home 'They + Peter will go home.' 'He + Peter will go home.'

b. Oni pojdut domoj. they will-go home 'They will go home.' *'He will go home.

The combination of plural pronoun + comitative phrase, understood as in (1b) and its counterparts in (3a) and (4a), is standardly referred to as the "Plural Pronoun Construction", hereafter the "PPC". In this paper, we show how the meaning of the PPC is derived, and what syntactic structure corresponds to it. 


\subsection{Comitative Conjuncts \& Comitative Adjuncts}

The contrast in (1) and (2) shows that the special interpretation of the PPC depends on the presence of a comitative phrase. Our story therefore begins with a discussion of comitatives.

Comitative phrases in Russian can be argued to occur in at least two distinct functions: as conjuncts and as adjuncts. (5) illustrates these uses. Note that whereas (5a) is does not entail that the girls and boys danced together, (5b) does.

\section{Mal'chiki s devochkami tancevali boys-NOM with girls-INSTR danced}

a. 'The boys and the girls danced.'

b. 'The boys danced with the girls.'

Comitative Conjunct Comitative Adjunct

This difference in interpretation is correlated by Vassilieva (2001) with a difference in structure. Comitative conjuncts are assigned the approximate structure in (6a), and interpreted as expressing coordination, parallel to true conjunctions (6b).
a. Comitative Conjunct

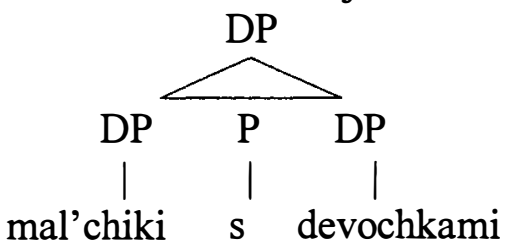

b. True Conjunction

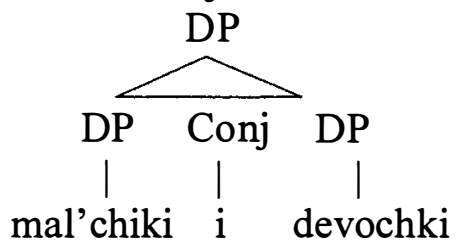

By contrast, comitative adjuncts are assigned the structures in $(7 \mathrm{a}, \mathrm{b})$ and are interpreted as modifiers expressing accompaniment.

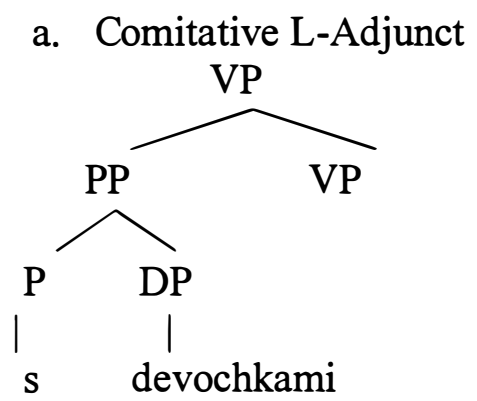

b. Comitative R-Adjunct

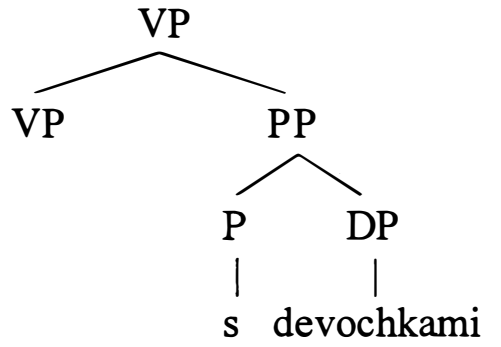

As Vassilieva (2001) discusses, the correlation of structure and interpretation in (6) and (7) correctly predicts a number of important distributional differences between comitative conjuncts and adjuncts that have been noted in the literature over the years (McNally 1993, Camacho 1996, Progovac 1993).

\subsection{Agreement}

Consider a string like (8), where a singular Nominative-marked subject immediately precedes a comitative and the verb. When the comitative is a conjunct, the 
structure will as in (9a), parallel to a true conjunction (9b). The subject is a coordination of singulars, and hence plural, requiring plural agreement on the verb.

$\begin{array}{lll}\text { Ivan } & \text { s } & \text { Petej V } \\ \text { I-NOM } & \text { with P-INSTR }\end{array}$
a. [DP Ivan s Petej] ushli domoj. I-NOM with P-INSTR went-PL home 'Ivan and Peter went home.'
b. [DP Ivan i Petja ] ushli domoj. I-NOM and P-NOM went-PL home 'Ivan and Peter went home.'

By contrast, when a singular Nominative-marked subject precedes an adjunct comitative, the structure is as in (10), where the comitative is left adjoined to VP and not part of the subject at all. In this case we have a singular subject, requiring singular agreement on the verb:

$$
\begin{aligned}
& \text { Ivan [vP s Petej [vp ushol domoj. ]] } \\
& \text { I-NOM with P-INSTR went-SG home } \\
& \text { 'Ivan went home with Peter.' }
\end{aligned}
$$

The prediction is thus that in cases like (8), verb agreement should correlate with conjunct versus adjunct readings. Specifically, plural agreement should entail conjunct semantics, and singular agreement should entail adjunct semantics. This prediction is correct, as the glosses show.

\subsection{Discontinuity with the Subject (McNally 1993)}

A second prediction concerns adjacency to the subject. Since comitative adjuncts can attach on the right of VP (7b), they are predicted to be able to occur nonadjacent to the subject. This possibility is illustrated in (11a), with the structure in (11b). Note that the verb agreement is singular, as expected:
a. Ivan ushol domoj s Petej.
I-NOM went-SG home with P-INSTR
'Ivan went home with Peter.'
b. Ivan [vp [vp ushol domoj] s Petej. ] I-NOM went-SG home with P-INSTR
'Ivan went home with Peter.'

By contrast, comitative conjuncts will be able to occur disjoint from the subject only if the comitative phrase can escape the larger conjunction and extrapose rightward. (12a) shows that this is not possible with true conjunctions, presumably as a result of island constraints. Equally, it is not possible with a comitative 
conjunct (12b) (where verb agreement is again used to force the conjunct interpretation):
a. *Ivan ushli domoj i Petja.
I-NOM went-PL home and P-NOM
'Ivan and Peter went home.'
b. *Ivan ushli domoj s Petej.
I-NOM went-PL home with P-INSTR
'Ivan and Peter went home.'

Thus dislocation becomes another diagnostic for distinguishing comitative conjuncts and adjuncts: only the latter can appear divided from the subject by other sentence material.

\subsection{Compatibility with V (Vassilieva 2001)}

A third diagnostic concerns verb choice. Under (7a,b) comitative adjuncts are essentially adverbs expressing accompanied action. It follows that they should cooccur only with verbs permitting modifiers of this kind. Verbs like uxodit' 'go, leave' are semantically compatible with the expression of accompanied action; it makes sense to speak of going with someone, etc. Compare this, however, with a verb like znat' 'know', where it is not sensible to speak of knowing French with someone. Similarly for other non-agentive predicates like nedoverjat' 'admire,' napominat' 'distrust,' vosxishchat 'sja' 'resemble,' etc.

This point suggests that we should be able to distinguish comitative conjuncts and adjuncts by verb choice. (13) and (14) confirm this prediction. (13a,b) show that when the verb znat' 'know' is used, only plural agreement is possible, indicating a conjunct structure, like a true conjunction (13c). (14) shows that dislocation of a comitative, which forces an adjunct analysis, is also unacceptable with znat' 'know':

a. \#Ivan s Petej znaet nemeckij.

I-NOM with P-INSTR know-SG German-ACC \#'Ivan knows German with Peter.'

b. Ivan s Petej znajut nemeckij.

I-NOM with P-INSTR know-PL German-ACC

'Ivan and Peter know German.'

c. Ivan i Petja znajut nemeckij.

I-NOM and P-NOM know-PL German-ACC

'Ivan and Peter know German.'

(14) \#Ivan znaet nemeckij s Petej. I-NOM know-SG German-ACC with P-INSTR \#'Ivan knows German with Peter.' 
Parallel facts hold with other non-agentive predicates. Thus acceptability of a comitative with non-agentive verbs like znat' 'know' becomes diagnostic for conjunct status.

\subsection{Wh-Extraction (McNally 1993)}

The example in (15) is ambiguous between the two readings given in a and $b$. These readings arise from the two possible structures in $(16 \mathrm{a}, \mathrm{b})$ (resp.), where $s$ Lenoj 'with/to Lena' is an adjunct in the first, and a conjunct in the second:

Masha govorila ob Ivane s Lenoj. M-NOM talked about Ivan with L-INSTR

a. 'Masha talked about Ivan with/to Lena.'

b. 'Masha talked about Ivan and Lena.'
a. Masha govorila [PP ob Ivane ] [PP s Lenoj]
Adjunct
b. Masha govorila [PP ob [DP Ivane s Lenoj ]]
Conjunct

The difference in structure predicts a difference in extraction possibilities. Extraction of a phrasal adverb is licit in Russian, whereas extraction of a single conjunct is blocked by the Coordinate Structure Constraint. It follows that whmovement of the comitative should disambiguate in favor of the adjunct reading. This prediction is correct, as (17) shows:

[S kem ] Masha govorila ob Ivane? with whom M-NOM talked about Ivan
a. 'With whom did Masha talk about Ivan?'
b. *'Who did Masha talk about Ivan and?'

Extractability of the comitative is thus another test for adjunct vs. conjunct status.

\subsection{Binding (McNally 1993)}

Finally, there are anaphor binding facts distinguishing conjunct and adjunct comitatives. In (18a) the possessive anaphor svoju 'self' s' must be understood as plural, taking the whole of Masha s Ivanom 'Masha and Ivan' as its antecedent, as occurs with true conjunction (18b):

a. Masha s Ivanom chitajut svoju knigu. M-NOM with I-INSTR read-PL REFL book 'Masha and Ivan read their book.'

b. Masha i Ivan chitajut svoju knigu. M-NOM and I-NOM read-PL REFL book 'Masha and Ivan read their book.' 
By contrast the possessive anaphor in (19) must be understood as singular, taking only the Nominative subject Masha as its antecedent

$$
\begin{aligned}
& \text { Masha s Ivanom chitajet svoju knigu. } \\
& \text { M-NOM with I-INSTR read-SG REFL book } \\
& \text { 'Masha reads her book with Ivan.' }
\end{aligned}
$$

This behavior follows from their respective structures. In (18a) $s$ Ivanom 'with Ivan' is a comitative conjunction, as shown by the plural verb agreement. The structure is thus as in (20a), where the only c-commanding antecedent for the reflexive is the entire conjunction Masha s Ivanom 'Masha and Ivan'. By contrast, in (19) $s$ Ivanom 'with Ivan' is a comitative adjunct, as shown by singular verb agreement. Its structure is as in (20b), where only the Nominative subject Masha c-commands the reflexive, and hence only the Nominative subject is a possible antecedent for it:
a. [DP Masha $\mathrm{i}$ Ivanom $]_{\mathrm{k}}$ chitajut svoju $*_{\mathrm{i}} / *_{\mathrm{j}} / \mathrm{k}$ knigu. M-NOM with I-INSTR read-PL REFL book 'Masha and Ivan read their book.'
b. Masha $a_{i}\left[v P\left[P P S \quad \text { Ivanom }_{j}\right]_{\text {chitajet }}\right.$ svoju $_{i} / *_{j}$ knigu. ] M-NOM with I-INSTR read-SG REFL book 'Masha reads her book with Ivan.'

Thus binding is also a test for conjunct vs. adjunct status for comitatives.

\subsection{PPC Comitatives are Neither Conjuncts nor Adjuncts}

Given the well-founded distinction between comitative conjuncts and adjuncts, it is natural to ask whether the comitative in the Plural Pronoun Construction can be reduced to one of these two types. Interestingly, as discussed in Vassilieva (2001), PPC comitatives do not pattern consistently either as conjuncts or as adjuncts.

Like a comitative conjunct, and unlike a comitative adjunct, the PPC comitative can occur with verbs like znat' 'know' (21a), the pronoun + comitative can bind a plural reflexive, understood as denoting to their joint reference (21b), and the PPC comitative cannot be $w h$-extracted (23c):
a. My s Petej znajem nemeckij. we with P-INSTR know-PL German
'Peter and I know German.'
My s Petej chitaem svoju knigu
(V Compatibility) we with P-INSTR read-PL REFL book
(Anaphor construal) 'Peter and I read our book.'
c. * $\left.{ }^{\mathrm{S}} \mathrm{kem} \quad\right] \mathrm{my}$ znajem nemeckij? (Extractability) with whom we know-PL German 'I and whom know German?'


On the other hand, like a comitative adjunct, and unlike a comitative conjunct, the PPC comitative can be displaced from the subject (22):

My znajem s Petej nemeckij. (Discontinuity)

we know-PL with P-INSTR German

'Peter and I know German.'

The PPC comitative also shows other differences from comitative conjuncts. As we have seen, comitative conjunctions in $s$ 'with' are highly similar to true conjunctions in $i$ 'and' $(23 \mathrm{a}, \mathrm{b})(=(13 \mathrm{~b}, \mathrm{c}))$. The two are typically interchangeable:
a. Ivan s Petej znajut nemeckij.
I-NOM with P-INSTR know-PL German-ACC 'Ivan and Peter know German.'
b. Ivan i Petja znajut nemeckij. I-NOM and P-NOM know-PL German-ACC 'Ivan and Peter know German.'

By contrast, the PPC has no equivalent true coordination; exchanging $i$ 'and' for $s$ 'with' alters its meaning entirely (24):
a. My s Petej znajem nemeckij. we with P-INSTR know-PL German 'Peter and I know German.'
b. My i Petja znajem nemeckij. we and P-NOM know-PL German 'Peter and us know German.'

Furthermore, there is an asymmetry in the PPC not found with comitative conjuncts. Whereas the elements in a comitative conjunction can be freely inverted $(25 \mathrm{a}, \mathrm{b})$, this is not true in the PPC. In the latter, the plural pronoun must come first, and the verb must agree with it $(26 a, b)$ :
a. Masha s Sashej tancevali.
M-NOM with S-INSTR danced-PL
'Masha and Sasha danced.'
b. Sasha s Mashej tancevali.
S-NOM with M-INSTR danced-PL
'Sasha and Masha danced.'

(26) a. My s Petej tancevali.

we with P-INSTR danced-PL

'Peter and I danced.'

b. *Petja s nami tancevali/tanceval.

P-NOM with us-INSTR danced-PL/danced-SG

'Peter and I danced.' 
Finally, whereas Russian pronouns cannot occur in comitative coordination (27a), and are dispreferred in true coordinations with $i$ 'and' (27b) (Urtz 1994), the PPC requires a plural pronoun.
a. *Ty so mnoj tancevali. you(sg) with me-INSTR danced-PL 'You and I danced.'
b. Ty i ja tancevali. (dispreferred) you(sg) and me-NOM danced-PL 'You and I danced.'

\subsection{DP Adjuncts?}

It is worth noting a final possibility that has been proposed in the literature, namely that the Plural Pronoun comitative is not a VP adjunct, but rather a DP adjunct, with structure approximately as in (28) This idea is suggested in den Dikken (2000), Ladusaw (1989), Progovac (1993) and Schwarz (1988):

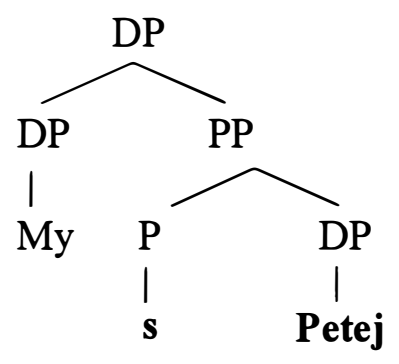

This idea does not appear promising to us. As we noted, the comitative in the PPC can be separated from the plural pronoun (recall (22) above). But as (29) shows, such separation is not possible with other comitatives that are plausibly identified as DP-adjuncts.
a. Devushka s kosoj sidela na divane.
(Extractability) girl with braid sat on sofa 'A girl with a braid sat on the sofa.'
b. *Devushka sidela s kosoj na divane.
c. *Devushka sidela na divane s kosoj.

Furthermore, if the PPC comitative were a DP adjunct to a plural pronoun, one might expect such an adjunct to co-occur with other personal pronouns, or other plural nominals. As (30) and (31) show, respectively, this is not correct. PPC comitatives apply only to plural pronouns.

a. *Ona s kosoj sidela na divane. she with braid sat on sofa 'She with a braid sat on the sofa.' 

b. *Ty so mnoj sideli na divane. you.SG with me sat on sofa 'You(sg) and I sat on the sofa.'

(31) Studenty s Petej sideli na divane. students with Peter sat on sofa
a. 'Students and Peter sat on the sofa.'
Comitative Conjunct
b. 'Students sat on the sofa with Peter.'
Comitative VP-adjunct
c. *'Students (including Peter) sat on the sofa.' *PPC

We draw a strong conclusion from these results. We think they indicate that attempts to analyze the PPC comitative either as a conjunct, or as a VP-/DP-adjunct are misguided. The data we have reviewed strongly suggest that despite surface status as an $s$-phrase, the Russian plural pronoun comitative is not an instance of either of the other two comitative construction types. Rather, we suggest that it corresponds to a new, third class.

\subsection{PPC Comitatives as Pronoun Complements}

The proposal we wish to advance about the PPC can be motivated by some simple, but familiar observations about the relations between singular and plural pronouns.

\subsection{Plural Pronouns as "Incomplete" Terms}

In explaining the relation between $I$ and we, and between you (singular) and you (plural), it is commonplace to put things like this: "we refers to the speaker plus some other individuals" or "you refers to the addressee plus someone else". In other words, we describe the reference of the plural pronoun as if they were derived from the reference of the corresponding singular pronoun by the addition of individuals $\Delta(32 \mathrm{a}, \mathrm{b})$. By extension, we might describe the third person plural in terms of the reference of the third singular plus others (32c): [1]

$$
\begin{array}{lll}
\text { a. } \text { we } & =I & +\Delta \\
\text { b. } \text { you }(\mathrm{pl}) & =\text { you }(\mathrm{sg}) & +\Delta \\
\text { c. they } & =\text { he/shelit } & +\Delta
\end{array}
$$

This way of viewing plural pronouns is not only semantically natural (at least for the 1st and 2nd person forms), it is also morphologically natural in certain languages. Vietnamese forms plural pronouns directly from singulars by addition of a suffix -men which derives from a Chinese word meaning 'people', and which is reserved for pronouns (33). Similarly, Melanesian Pidgin forms plural pronouns from singulars using a suffix -fela which is not a general plurality marker. 
Vietnamese (Nguen 1996)

Melanesian Pidgin (Mühlhäusler 1989)

\begin{tabular}{llllllll}
\hline a. & tao & $1 \mathrm{sg}$ & chúng tao $1 \mathrm{pl}$ & d. mi & $1 \mathrm{sg}$ & mi-fela & $1 \mathrm{pl}$ \\
b. & mày & $2 \mathrm{sg}$ & chúng mày $2 \mathrm{p}$ & e. $y u$ & $2 \mathrm{sg}$ & yu-fela & $2 \mathrm{pl}$ \\
c. & nó & $3 \mathrm{sg}$ & chúng nó $3 \mathrm{pl}$ & f. him & $3 \mathrm{sg}$ & him-fela & $3 \mathrm{pl}$
\end{tabular}

It is highly tempting to view the surface morphological composition in (33) as directly reflecting the intuitive semantic composition in (32).

Now observe that when we view plural pronouns as in (32), we are in effect claiming that along with a well-defined "singular nucleus", a plural pronoun also contain an unspecified, or "unsaturated" element $\Delta$ in its meaning. It is "incomplete" in the sense that until this element is specified, the pronoun fails to refer. This raises the interesting possibility that the grammar might actually provide a syntactic means for "filling in" this unspecified element, for example, by letting a phrase that is sister to the pronoun specify the content of $\Delta$, as shown schematically in (34). Note that such a phrase YP would function as a complement of the pronoun, completing its meaning. Note further that semantics of their combination would result in the reference of YP always being included in the reference of the plural pronoun.

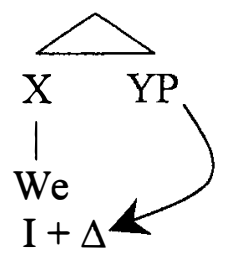

We wish to propose that plural pronouns in Russian (and in general) have the semantic composition in (32). Thus $m y$ 'we', $v y$ 'you(pl)', and oni 'they' are semantically complex, composed of a singular "core" plus an additional set whose content is left unspecified in its lexical meaning. Furthermore, we propose that the Russian Plural Pronoun Construction is precisely an instance of the structure in (34), where the comitative is a complement of the pronoun head D, supplying the unspecified individual(s) in the plural pronoun meaning (35):

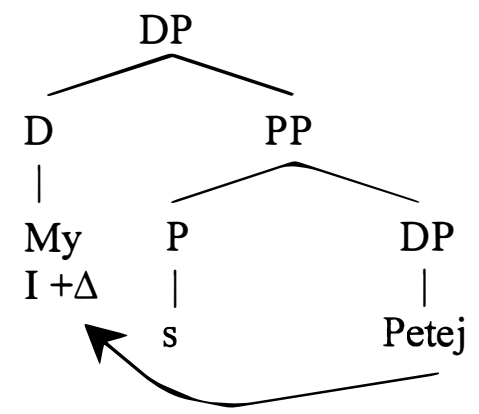

The complement hypothesis has an empirical consequence that seems to provide further evidence against an alternative adjunct account. Notice that if the comitative PP is indeed a pronoun complement, we would expect it to "saturate" the open position in the pronoun's meaning, blocking further complement comita- 
tives. This prediction is correct as (36a-c) show. Although it would be perfectly reasonable in general terms to specify other individuals in the group given by the plural pronoun, multiple comitatives of this kind are not possible:
a. *My s Petej s Ivanom pojd'om domoj. we with P-INSTR with I-INSTR will-go home 'Peter and Ivan and I will go home.'
b. ${ }^{*} V y$ s Petej s Ivanom pojd'ote domoj. you with P-INSTR with I-INSTR will-go home 'Peter and Ivan and you (sg) will go home.'
c. *Oni s Petej s Ivanom pojdut domoj. they with P-INSTR with I-INSTR will-go home 'Peter and Ivan and he will go home.'

At the same time, the complement account does allow for surface iteration of comitatives in PPCs of the kind shown in (37): [ [2,3]
a. My s vami s Petej pojd'om domoj. we with you-PL-INSTR with P-INSTR will-go home 'Peter and you(sg) and I will go home.'
b. My s nimi s Petej pojd'om domoj. we with them-INSTR with P-INSTR will-go home 'Peter and he and I will go home.'
c. Vy s nimi s Petej pojd'ote domoj. you-PL with them-INSTR with P-INSTR will-go home 'Peter and you(sg) and he will go home.'

These are instances of recursive PPCs, in which each comitative is a complement of the preceding pronoun. (37a), for example, receives the analysis in (38), where $s$ Petej 'with Peter' is the complement of vami 'you(pl)', and where the whole of $s$ vami s Petej 'with you with Peter' is the complement of my 'we':

$$
\text { [DP My [PP } \mathrm{s} \text { [DP vami [PP s Petej ]]]] }
$$

As predicted, despite the presence of two plural pronouns together with the comitative $s$ Petej 'with Peter', the interpretation of (37a) involves only three individuals.

The complement account also has the attractive general result of "completing the paradigm" for comitatives. Recall that comitative with-phrases in English have three main functions: as adjuncts to VP or DP (39), as something very like conjuncts with inherent reciprocal verbs (40), and as complements with certain verbs and adjectives (41):
a. John walked with Peter.
Adjunct With-phrases (VP or DP)
b. A girl with braids sat on the sofa. 
John collided with Peter. (cf. John and Peter collided.)

(41) a. John awarded Peter with a prize. Complement With-phrase

b. John was angry/happy with Peter.

On the proposal advanced here, comitative $s$-phrases in Russian have these three function as well: as adjuncts to VP or DP, as conjuncts to D, and also as complements to D.

\subsection{Formal Semantics for PPC Comitatives}

We make the complement hypothesis precise using the formalism of Larson and Segal (1995), in which sentences are assigned truth-values with respect to a context sequence $\sigma(42)$, and where the first four positions of any sequence (designated " $\sigma(a) ", " \sigma(b) ", " \sigma(c) "$ and $" \sigma(d) "$, respectively) are understood as the speaker, the addressee, the speaker time, and the speaker location in the context (43a). Indexical pronouns get their values through these elements $(43 b, c)$

$$
\operatorname{Val}(\mathrm{t}, \mathrm{S}, \sigma)
$$
a.
$\sigma(a) \quad \sigma(b)$
$\sigma(\mathrm{c})$
$\sigma(d)$
$\sigma=<$ speaker, addressee, speaker time, speaker location, ... >
b. $\operatorname{Val}(\mathrm{x},[\mathrm{D} I], \sigma) \quad$ iff $\mathrm{x}=\sigma(\mathrm{a})$
c. $\operatorname{Val}(\mathrm{x},[\mathrm{D} y o u], \sigma) \quad$ iff $\mathrm{x}=\sigma(\mathrm{b})$

Other positions in the sequence, identified by numerals, fix the reference of other deictic (but non-indexical) elements in the sentence (44a); the reference of nonindexical pronouns is determined through them (44b):
a. $\sigma(1) \quad \sigma(2) \quad \sigma(3)$ $\sigma=<$ spkr, adrs, spk time, spk loc $\mid$ Mary, John, the Eiffel Tower, ... > b. $\operatorname{Val}\left(\mathrm{x},\left[\mathrm{D} h e_{2}\right], \sigma\right)$ iff $\mathrm{x}=\sigma(2)$ (i.e., John)

Now let the distributive ("all of") interpretations of Russian person plurals be as in (45a-c), where these items are analyzed as determiners, following Postal (1969), and where " $\sigma(a) "$ refers to the speaker (with respect to context sequence $\sigma)$ :
a. $\operatorname{Val}(<\mathrm{X}, \mathrm{Y}>,[\mathrm{D} m y], \sigma) \quad$ iff $|(\{\sigma(\mathrm{a})\} \cup \mathrm{Y})-\mathrm{X}|=0$ "(all of) speaker + others $Y "$
b. $\operatorname{Val}(<\mathrm{X}, \mathrm{Y}>$, , $v y$ ], $\sigma)$ iff $|(\{\sigma(\mathrm{b})\} \cup \mathrm{Y})-\mathrm{X}|=0$ "(all of) addressee + others $Y "$
c. $\operatorname{Val}\left(\langle\mathrm{X}, \mathrm{Y}\rangle,\left[\mathrm{D} o n i_{\mathrm{i}}\right], \sigma\right)$ iff $|(\{\sigma(\mathrm{i})\} \cup \mathrm{Y})-\mathrm{X}|=0$ "(all of) he/she/it + others Y"


Under these rules, the pronouns are all relational; $Y$ specifies the set of individuals - in addition to the speaker, addressee, etc. - referred to by the plural pronouns.

Suppose further that the comitative PP $s$ Petej 'with Peter' is interpreted simply as the set $\mathrm{Y}$ containing Peter (46):

$$
\operatorname{Val}(\mathrm{Y},[\mathrm{pP} s \text { Petej }], \sigma) \quad \text { iff } \mathrm{Y}=\{\text { Peter }\}
$$

And let the semantics of a Determiner + PP complement be as given in (47), which simply identifies the value of the second argument of the determiner with the set given by the PP:

$$
\operatorname{Val}(X,[D P D P P], \sigma) \text { iff } \operatorname{Val}(<X, Y>, D, \sigma) \& \operatorname{Val}(Y, P P, \sigma)
$$

Identification of $\mathrm{Y}$ values for (45a) and (47) will yield the result in (48) for the full DP [DP my s Petej ] 'we with Peter':

$$
\begin{array}{ll}
\operatorname{Val}(\mathrm{X}, \text { my } s \text { Petej, } \sigma) & \text { iff } \mid(\{\sigma(\mathrm{a})\} \cup\{\text { Peter }\})-\mathrm{X} \mid=0 \\
\mathrm{Val}(\mathrm{X}, \text { my } s \text { Petej, } \sigma) & \text { iff } \mid\{\sigma(\mathrm{a}), \text { Peter }\}-\mathrm{X} \mid=0
\end{array}
$$

Thus the comitative supplies the "unsaturated" element in the interpretation of $m y$, as desired.

The formal results in (45)-(48) are directly comparable to the interpretations assigned, respectively, to a relational quantifier (49a), a nominal (49b), and the interpretation of a full quantified DP in which the latter is the complement of the former (49c):
a. $\operatorname{Val}(<\mathrm{X}, \mathrm{Y}>$, [D every ], $\sigma)$
iff $|Y-X|=0$
b. $\operatorname{Val}(\mathrm{Y},[\mathrm{NP}$ boy $], \sigma)$
iff $\mathrm{Y}=\{\mathrm{y}: \operatorname{boy}(\mathrm{y})\}$
c. $\operatorname{Val}(\mathrm{X},[\mathrm{DP}$ every boy $], \sigma)$
iff $|\{\mathrm{y}: \operatorname{boy}(\mathrm{y})\}-\mathrm{X}|=0$

In fact, the rule used to assemble a plural pronominal DP from its plural pronoun head D and comitative complement (PP) can be easily generalized to assemble a quantificational DP from its quantifier head D and nominal complement (NP), as in (50), where $\mathrm{X}$ ranges over $\mathrm{N}$ and $\mathrm{P}$ :

$$
\operatorname{Val}(X,[D P D X P], \sigma) \text { iff } \operatorname{Val}(<X, Y>, D, \sigma) \& \operatorname{Val}(Y, X P, \sigma)
$$

\subsection{Results \& Further Discussion}

We conclude now by briefly recalling the properties that distinguish PPC comitatives from comitative conjuncts $\&$ adjuncts, and seeing how the proposal advanced here fares with them.

Our analysis successfully accounts for various respects in which the PPC comitative behaves like a conjunct. Since the PPC comitative is not a modifier of $\mathrm{V}$, we correctly predict that it will be compatible with non-agentive Vs, as seen in (21a). And since its reference is included in the reference of the plural pronoun, 
we predict that it will also be included in the reference of any anaphor that is bound to the plural pronoun, as seen in (21b). (Examples repeated below).
a. [DP My [PP s Petej ]] znajem nemeckij. (V Compatibility) we with P-INSTR know-PL German 'Peter and I know German.'
b. [DPi My [PP S Petej ]] chitaem svoju knigu. we with P-INSTR read-PL REFL book 'Peter and I read our book.'
(Anaphor construal)

We also account for various respects in which PPC comitative behaves unlike a conjunct. First, we see why the PPC is not interchangeable with coordination $(24 a, b)$ : the comitative PP is a governed complement, not a second conjunct. We also see why the plural pronoun and $s$-phrase DP are not symmetrically invertible like conjuncts $(26 \mathrm{a}, \mathrm{b})$. The pronoun and comitative stand in a head complement relation, which is not symmetric. Finally, we see why the PPC is exempt from the constraint disfavoring coordinated pronouns in Russian (27a). Again, the PPC is not coordination, but rather complementation. The constraint on pronouns simply does not apply.
a. My s Petej znajem nemeckij. we with P-INSTR know-PL German 'Peter and I know German.'
b. My i Petja znajem nemeckij. we and P-NOM know-PL German 'Peter and us know German.'
a. My s Petej tancevali. we with P-INSTR danced-PL 'Peter and I danced.'
b. *Petja s nami tancevali/tanceval. P-NOM with us-INSTR danced-PL/danced-SG 'Peter and I danced.'
(27a) *Ty so mnoj tancevali. you(sg) with me-INSTR danced-PL 'You and I danced.'

There are two data points that our analysis does not obviously account for as it stands: the fact that the PPC comitative can occur discontinuous from the plural pronoun (22), and the fact that it cannot be questioned (21c). The former suggests that the comitative can be extracted from the complement of $D$, whereas the latter seems to imply that it cannot. 

'Peter and I know German.'

$*[S$ kem ] my znajem nemeckij?

with whom we know-PL German

'I and whom know German?'

(Extractability)

We are unable to resolve this issue at present, but we note that the behavior of the comitative seems to be identical in relevant respects to that of exception phrases, which (according to Keenan and Stavi 1983 and Larson 1991) are also D complements. Exception phrases also can appear discontinuous from the universal D that licenses them (51a-c), but cannot be wh-questioned (52): [4]
a. [DP Everyone except (for) Peter] danced.
b. Everyone danced [except (for) Peter.]
c. [Except (for) Peter] everyone danced.

a. *Except (for) whom did everyone dance?

b. *Who did everyone except (for) dance?

Note also that PPC comitatives appear to perform a semantic function which is similar, but opposite, to that of exception phrases. Where as the former add their reference to that of the $\mathrm{D}$ head, the latter subtract their reference from $\mathrm{D}$. It seems plausible to us, therefore, that a proper grasp of (22) and (21c) will lie with the understanding of a broader class of phenomena, which includes exceptive elements.

Finally, there are some broader comparative questions that this work naturally gives rise to. The account of the PPC we offer is based on an analysis of plural pronoun semantics that is presumably universal. This might lead one to expect the PPC in all languages. Nonetheless, although the PPC is widespread, it is not universal. English, for example, lacks this form. Why? What parameters govern this variation?

Relatedly, even in languages that do contain the PPC, plural pronouns are not required to take a comitative complement. What then is the analysis of the bare plural pronoun forms? Is there a covert comitative complement in the syntax, or is the pronoun somehow "detransitivized" in the lexicon? We leave these very interesting questions for future investigation. [5]

\section{Endnotes}

1. Kayne (2000) cites some interesting binding facts suggesting that they might be analyzed as in (29c). He notes that although they cannot c-command both of its antecedents without violating Principle C (ia,b), it can apparently c-command one of its antecedents (ic): 
(i)
a. John $n_{\mathrm{i}}$ told Bill $\mathrm{j}_{\mathrm{j}}$ that they ${ }_{\{\mathrm{i}, \mathrm{j}\}}$ should leave.
b. *They $\{\mathrm{i}, \mathrm{j}\}$ told John $\mathrm{i}_{\mathrm{i}}$ that Bill $\mathrm{j}_{\mathrm{j}}$ should leave.
c. $J_{\text {John }}$ told me that they ${ }_{\{i, j\}}$ decided that Bill $l_{j}$ should leave.
d. $J \mathrm{Jhn}_{\mathrm{i}}$ told me that they $\mathrm{i}_{\mathrm{i}}$ ecided that Bill $\mathrm{j}_{\mathrm{j}}$ should leave.

This fact is accounted for if they bears only single index, equivalent to a singular pronoun (id). This idea is very natural under the proposal that they is essentially he/she/it $+\Delta$.

2. We are grateful to Chris Barker for pointing out the importance of cases like (37a,b).

3. Recursive PPC examples are perceived as cumbersome (although grammatical) by Russian speakers. Furthermore recursive PPCs, like PPCs in general, are subject to an independent constraint requiring pronouns of a lower person to be structurally superior to pronouns of a higher person. Thus 1 st person pronouns must be superior to 2nd person, which must in turn be superior to 3rd person. This effect is observed in simple PPCs like (ia,b) (from Vassilieva 2001):

(i)
a. My s nej tancuem.
we with her dance
'She and I dance.'
b. *Oni s mnoj tancujut. they with me dance
'She and I dance.'

This accounts for the unacceptability of the recursive PPCs in (iia-c), which are variants of (37a-c), respectively:

(ii) a. *Vy s nami s Petej pojd'ote domoj. you(pl) with us-INSTR with P-INSTR will-go home 'Peter and you(sg) and I will go home.'
b. *Oni s nami s Petej pojdut domoj. They with us-INSTR with P-INSTR will-go home 'Peter and he and I will go home.'
c. *Oni s vami s Petej pojdut domoj. they with you(pl)-INSTR with P-INSTR will-go home 'You, he and Peter will go home.'

4. See also Reinhart (1991) and von Fintel (1993) for more on exceptiveconstructions.

5. Vassilieva (in progress) develops an extension of ideas by Rizzi (1986), proposing that some languages contain a small pro complement of the pronoun in the syntax, whose value is fixed by context, whereas other languages "saturate" the comitative argument of the plural pronoun in the lexicon, in effect, detransitivizing it.

\section{References}

Camacho, J. (1996) "Comitative Coordination in Spanish," In: C. Parodi et al (eds.) Aspects of Romance Linguistics. (pp. 107-122) Georgetown University Press, Washington, D.C. 
Camacho, J. (2000) "Structural Restrictions on Comitative Coordination," Linguistic Inquiry 31, 366-75.

Dalrymple, M., I. Hayrapetian and T. Holloway King (1998) "The Semantics of the Russian Comitative Construction," NLLT 16: 597-631.

Den Dikken, M., A. Lipták and Z. Zvolenszky (2000). "On inclusive reference anaphora: New perspectives from Hungarian," Paper presented at CUNY Linguistics Colloquium, October 19, 2000.

Kayne, R. (2000) "Binding Theory and Movement" Paper presented at SUNY Linguistics Colloquium, November 13, 2000

Keenan, E. and Y. Stavi (1983) "A Semantic Characterization of Natural Language Determiners," Linguistics and Philosophy 9: 253-326.

Ladusaw, W. (1989) "Group Reference and the Plural Pronoun Construction. In: Papers on the Plural Pronoun Construction and Comitative Coordination. UCSC Syntax Research Center Report SRC-89-02, pp. 1-7.

Larson, R. (1991) "The Projection of DP and DegP". unpublished ms. SUNY Stony Brook.

Larson, R. and G. Segal (1995) Knowledge of Meaning. Cambridge: MIT Press.

McNally, L. (1993) "Comitative Coordination: A Case Study in Group Formation," NLLT 11: 347-379.

Mühlhäusler, P. (1989) "A Review of Roger Keesing's (1988) Melanesian Pidgin and the Oceanic Substrate. Stanford: Stanford University Press," Studia Linguistica 13: 459-475.

Nguen, P. (1996) Personal Pronouns and Pluralization in Vietnamese ," Mon Khmer Studies 25: 7-14.

Postal, P. (1969) "On the So-Called Pronouns in English," In D.Reibel and S.Shane (eds.) Modern Studies in English. Englewood Cliffs, NJ: PrenticeHall. 201-224.

Progovac, L. (1993) "Slavic and the Structure for Coordination," Proceedings of FASL 5 (pp. 207-223) Slavica Publishers, 207-223.

Reinhart, T. (1991) "Elliptic Conjunctions - Non-Quantificational LF," In A. Kasher (ed.) The Chomskyan Turn. (pp. 360-384) Oxford: Basil Blackwell.

Rizzi. L. (1986) "Null Objects in Italian and the Theory of pro," Linguistic Inquiry 17:501-557.

Schwarz, L. (1988) "Asymmetric Feature Distribution in Pronominal Coordinations," In: M. Barlow and J. Greenberg (eds.) Agreement in Natural language: Approaches, Theories, and Descriptions. (pp. 237-249) Stanford: Center for the Study of Language and Information. .

Urtz, B. (1994) The Syntax, Semantics, and Pragmatics of a Nominal Conjunction: The Case of Russian S. PhD thesis,. Harvard University: Cambridge.

Vassilieva, Masha. (2001) "On the typology of Russian comitative constructions," Proceedings of FASL 9, Slavica Publishers.

Vassilieva, Masha. (in progress) Russian Comitative Constructions. $\mathrm{PhD}$ thesis, SUNY, Stony Brook.

Von Fintel, K. (1993) "Exceptive Constructions," Natural Language Semantics 1: 123-148. 